\title{
Editorial
}

\section{Introductory Comments: Special Issue of EJOP (May 2012) on Memory}

\author{
Rhian Worth ${ }^{\star a}$ \\ äBangor University, Bangor, UK.
}

Welcome to Europe's Journal of Psychology Special Issue on Memory. This issue will focus entirely on research in the memory field and present a diverse range of studies within this area.

Research into memory, specifically, experimental research can traced back to the highly influential work of Hermann Ebbinghaus $(1885,1913)$. Originally published in German in Über das Gedächtnis, Untersuchungen zur experimentellen Psychologie (translated into English in 1913 as Memory. A Contribution to Experimental Psychology) this piece of work has played a pivotal role in memory research ever since. Over a century later since its initial publication and research into memory is thriving within psychology and not only. In the last year alone a search through PsychINFO using memory as general search finds that over 400 memory articles have been published in peer reviewed journals on this topic. Twenty years ago this figure stood at just 250. In addition, there are a large number of research laboratories which exist worldwide whose research is primarily focused on memory. Articles on memory have long been a staple of the research submitted to EJOP. Given the above, the idea of putting together a special issue of EJOP was suggested. The aim of this special issue is to showcase some of the interesting research currently taking place in memory studies. The articles included come from across the globe including Iran, South Africa, Spain, the United Kingdom, and the United States, and showcase research by researchers and academics from across the field. A full list of the authors and articles can be found in the content list for this issue and in Table 1 further on in this introduction.

A brief overview of these articles clearly demonstrates the diversity of topics included in this issue and this range is indicative of the field in general (see Table 1). Memory research employs different types of methods and techniques including case studies, behavioral methods, and neuroimaging to name but a few. Research topics are also wide ranging, and cover research which is both theory-based and/or applied. This diversity is well reflected in our special issue.

The special issue begins with an editorial written by Eryn Newman and Elizabeth Loftus which is based on a fictional conversation between the authors and Hermann Ebbinghaus. This is followed by two interviews which 
Table 1.

Article Titles and Research Areas

\begin{tabular}{|c|c|c|}
\hline Author(s) & Title & Research Area/Topic \\
\hline Newman \& Loftus & $\begin{array}{l}\text { Updating Ebbinghaus on the Science of } \\
\text { Memory. }\end{array}$ & $\begin{array}{l}\text { An editorial by Newman and Loftus update } \\
\text { Ebbinghaus. }\end{array}$ \\
\hline Williamson & Music to Our Ears. & $\begin{array}{l}\text { In this interview Victoria Williamson discusses } \\
\text { past and present research on memory and } \\
\text { music, and directions in her current research. }\end{array}$ \\
\hline Annese & $\begin{array}{l}\text { Brain Observatory and the Continuing Study } \\
\text { of H.M. }\end{array}$ & $\begin{array}{l}\text { In this interview Jacopo Annese discusses } \\
\text { research at the Brain Observatory, memory } \\
\text { and H.M. }\end{array}$ \\
\hline Estudillo & $\begin{array}{l}\text { Facial Memory: The Role of the Pre-existing } \\
\text { Knowledge in Face Processing and } \\
\text { Recognition. }\end{array}$ & $\begin{array}{l}\text { Estudillo considers the impact pre-existing } \\
\text { knowledge of faces has on processing. }\end{array}$ \\
\hline Polage & $\begin{array}{l}\text { Making up History: False Memory of Fake } \\
\text { News Stories. }\end{array}$ & $\begin{array}{l}\text { Polage examines familiarity of false news } \\
\text { stories and the impact on truthfulness, } \\
\text { plausibility, and source. }\end{array}$ \\
\hline Hamidi \& Noorafkan Roohi & $\begin{array}{l}\text { Manufacture and Validation of New Negative } \\
\text { Priming Measurement for Studying Individual } \\
\text { Differences in Working Memory. }\end{array}$ & $\begin{array}{l}\text { In this article Hamidi and Noorafkan Roohi } \\
\text { discuss their research on negative priming. }\end{array}$ \\
\hline Witt & $\begin{array}{l}\text { The Impact of Mathematics Anxiety on Primary } \\
\text { School Children's Working Memory. }\end{array}$ & $\begin{array}{l}\text { Witt explores whether the presence of digits } \\
\text { can trigger anxiety and the impact of } \\
\text { mathematic anxiety on working memory in } \\
\text { primary school children. }\end{array}$ \\
\hline Perfect \& Stark & $\begin{array}{l}\text { Unconscious Plagiarism in Recall: Attribution } \\
\text { to the Self, but not for Self-relevant Reasons. }\end{array}$ & $\begin{array}{l}\text { In this article Perfect and Stark look at } \\
\text { unconscious plagiarism and the improvement } \\
\text { effect. }\end{array}$ \\
\hline Vredeveldt, Baddeley, \& Hitch & $\begin{array}{l}\text { The Effects of Eye-Closure and "Ear-Closure" } \\
\text { on Recall of Visual and Auditory Aspects of a } \\
\text { Criminal Event. }\end{array}$ & $\begin{array}{l}\text { Vredeveldt, Baddeley and Hitch examine } \\
\text { eye-closure and "ear-closure" in this article } \\
\text { which also considers theoretical and practical } \\
\text { implications. }\end{array}$ \\
\hline Brescó De Luna \& Rosa & $\begin{array}{l}\text { Memory, History, and Narrative. Shifts of } \\
\text { Meaning when }(\mathrm{Re}) \text { constructing the Past. }\end{array}$ & $\begin{array}{l}\text { In this article Brescó De Luna and Rosa } \\
\text { discuss the socio-cultural dimensions of } \\
\text { memory. }\end{array}$ \\
\hline
\end{tabular}

Note: Articles listed in Table 1 appear according to the order they appear in the issue.

discuss some aspects of ongoing and current research in memory. The interview with Victoria Williamson (Lecturer and Co-Director of MSc in Music, Mind and Brain at Goldsmiths, University of London) focuses on her past and present research on memory and music, some main directions in current memory research and provides an insight into Victoria's sources of inspiration in her career. Jacopo Annese (director of the Brain Observatory, University of California, San Diego) discusses research at the Brain Observatory, memory, H.M., and provides an insight into the future of project H.M.

One line of research in this special issue is that of face processing. In the first research article in this issue Alejandro Estudillo examined 'familiarity and face processing' and his article explores behavioural, electrophysiological and neuroimaging evidence from this area. Another line of research is false stories and memory. In 'making up history' Danielle Polage looks at false news stories and their impact on whether participants who had heard them during the study rated them as more truthful, and plausible compared to participants who had never heard the false story before. Following this, Farideh Hamidi and Nasim Noorafkan Roohi looked at reliability and the negative priming 
effect with the findings of their research showing correlations between the variables and validating the measure of negative priming.

In a study involving primary school children Marcus Witt explored the impact of mathematic anxiety on working memory and whether the presence of digits can trigger an anxious reaction. Timothy Perfect and Louisa-Jayne Stark examined, in two experiments, unconscious plagiarism and sources or mechanisms for the improvement effect. Following this Annelies Vredeveldt, Alan Baddeley and Graham Hitch present two experiments looking at eye-closure and "ear-closure" and discuss the practical implications. History, narratives and memory feature in Ignacio Brescó de Luna and Alberto Rosa's theoretical contributions article in which the authors discuss the socio-cultural dimensions of the phenomenon, particularly in narratives.

\section{Concluding Comments}

It is hoped that these articles demonstrate not only the diverse research taking place in the field at present but also how interesting and informative this research is. Furthermore, it is hoped that this issue emphasises the richness of memory research and its importance in both theoretical and applied psychology. The articles here represent only a small fraction of what is taking place in this field and hopefully this issue will also inspire readers to consider memory as a research topic in their future work.

To conclude this introduction, I would like to thank everyone who has contributed to the special issue for their hard work and co-operation throughout this process. Without their contribution this issue would not have been possible. I would like to thank the authors for their contributions, their willingness to contribute to the issue and their patience and co-operation throughout the editorial process which has been essential in putting together this special issue. I would also like to thank the editor (Vlad Glaveanu) and the editorial team for their hard work on the special issue. We hope you all enjoy reading this issue as much as we've all enjoyed putting it together.

\section{References}

Ebbinghaus, H. (1885). Über das Gedächtnis. Untersuchungen zur experimentellen Psychologie. Leipzig: Duncker \& Humblot.

Ebbinghaus, H. (1913). Memory. A contribution to experimental psychology (H. A. Ruger, \& C. E. Bussenius, Trans.). New York: Columbia University.

\section{About the Author}

Rhian Worth is a teaching fellow at Bangor University, Wales. Her interest in memory began while studying for a degree in psychology. This interest in memory has continued throughout her postgraduate studies. Her previous research has primarily looked at retrieval-induced forgetting. This continues to be her main field of research although she also has a keen interest in other areas of memory particularly actions, eyewitness testimony and music. 